\title{
Synergistic Antibiofilm Effects of Ultrasound and Phenyllactic Acid against Staphylococcus aureus and Salmonella enteritidis
}

\author{
Jiaojiao Zhang ${ }^{1,2}$, Debao Wang ${ }^{2}$, Jinyue Sun ${ }^{2}$, Zhilan Sun ${ }^{2}$, Fang Liu ${ }^{1,2, *}$, Lihui Du ${ }^{3, *}$ and Daoying Wang ${ }^{2}$ \\ 1 School of Food and Biological Engineering, Jiangsu University, Zhenjiang 212013, China; \\ jjz1234560722@163.com \\ 2 Key Lab of Food Quality and Safety of Jiangsu Province-State Key Laboratory Breeding Base, \\ Nanjing 210014, China; Debaowang_2021@163.com (D.W.); jinyue952021@163.com (J.S.); \\ sunzhilan@jaas.ac.cn (Z.S.); daoyingwang@yahoo.com (D.W.) \\ 3 Key Laboratory of Grains and Oils Quality Control and Processing, Collaborative Innovation Center for \\ Modern Grain Circulation and Safety, College of Food Science and Engineering, \\ Nanjing University of Finance and Economics, Nanjing 210023, China \\ * Correspondence: fangliu82@163.com (F.L.); ddabc_2000@163.com (L.D.)
}

Citation: Zhang, J.; Wang, D.; Sun, J.; Sun, Z.; Liu, F.; Du, L.; Wang, D. Synergistic Antibiofilm Effects of Ultrasound and Phenyllactic Acid against Staphylococcus aureus and Salmonella enteritidis. Foods 2021, 10 2171. https://doi.org/10.3390/ foods10092171

Academic Editor: Efstathios Giaouris

Received: 22 July 2021

Accepted: 30 August 2021

Published: 13 September 2021

Publisher's Note: MDPI stays neutral with regard to jurisdictional claims in published maps and institutional affiliations.

Copyright: (c) 2021 by the authors. Licensee MDPI, Basel, Switzerland. This article is an open access article distributed under the terms and conditions of the Creative Commons Attribution (CC BY) license (https:// creativecommons.org/licenses/by/ $4.0 /$ )

\begin{abstract}
This study evaluated the effect of the combination of ultrasound and phenyllactic acid (PLA) on inactivating Staphylococcus aureus and Salmonella enteritidis biofilm cells and determined the possible antibiofilm mechanism. S. aureus and S. enteritidis biofilm cells were separately treated with ultrasound (US, $270 \mathrm{~W}$ ), phenyllactic acid (PLA, $0.5 \%$ and $1 \%$ ), and their combination (US + 0.5\% PLA, and US $+1 \%$ PLA) for 5, 10, 20, 30, and $60 \mathrm{~min}$. Biofilm inactivation, polysaccharide, and respiratory chain dehydrogenase assays were conducted. US and PLA had a synergistic effect on inactivating bacterial cells in S. aureus and S. enteritidis biofilms. The combination of US and PLA significantly decreased the contents of soluble and insoluble polysaccharides and the activity of respiratory chain dehydrogenase in the biofilm cells compared to the single treatment. Confocal laser scanning microscopy, scanning electron microscopy, and intracellular adenosine-triphosphate (ATP) analyses indicated that the combination of US and PLA seriously destroyed the cell membrane integrity of the $S$. aureus and S. enteritidis biofilms and caused the leakage of intracellular ATP. These findings demonstrated the synergistic antibiofilm effect of US combined with PLA and offered a research basis for its application in the food industry.
\end{abstract}

Keywords: Staphylococcus; Salmonella; biofilm; dehydrogenase; polysaccharides

\section{Introduction}

Food safety has been a serious threat to people's health given the frequent outbreak of foodborne diseases and has attracted increasing attention worldwide [1]. Foodborne pathogens, such as Staphylococcus aureus and Salmonella enteritidis, are of worldwide concern due to their latent hazards to food security and public hygiene [2]. The United States recalled 31 foods from the food market due to S. enteritidis (https: / /www.fda.gov / Food/ Recalls, accessed on 24 January 2019). In China, 25\% of bacterial poisoning incidents were caused by $S$. aureus [3]. S. aureus and S. enteritidis can form biofilms on solid surfaces $[4,5]$. A biofilm comprises strongly enclosed microorganisms that cling to a surface and/or to each other, generating complex actionable circumstances [6-8]. Biofilms are found on food contact structures, such as band carriers, vessels, and pipes [9]. The formation of biofilms provides protection for foodborne pathogens and ensures that bacterial cells can adapt to unfavorable growth conditions. The elimination of pathogen biofilms is the key to ensure food safety.

Ultrasonic sterilization (US) is an effective method that can inactivate bacteria and is more suitable for liquid foods [10]. This method can inactivate common foodborne pathogens, such as Listeria and Escherichia coli, in dairy products and can ensure the 
preservation of their nutritional composition [11]. In addition, US is environmentally friendly and can be used to clean the surfaces of machines in the food industry $[12,13]$. However, a single ultrasonic treatment can only inactivate Cronobacter sakazakii biofilm cells by $0.2 \log \mathrm{CFU} / \mathrm{cm}^{2}$, indicating the limited effect of this process on removing biofilm cells [14]. Selan et al. [15] found that when ultrasound and antibiotics work together, on the basis of ensuring the same bactericidal effect, the presence of ultrasound can reduce the dose of antibiotic ampicillin. Alenyorege et al. [16] used the combination of ultrasound and sodium hypochlorite and found that it significantly reduced the number of Listeria innocua. Duarte et al. [17] found that the combined ultrasound and dichloroisocyanurate had significantly improved the antibacterial effect. In addition, ultrasound can improve the antibacterial effect of oregano essential oil and organic acids $[18,19]$. Phenyllactic acid (PLA) has a broad spectrum of effective antibacterial activity against many Gram-positive bacterial species, including S. aureus and Listeria monocytogenes, as well as Gram-negative bacterial species, including S. enteritidis and E. coli. Liu et al. [20] reported that PLA decreased the biofilm formation of Enterococcus faecalis. Liu et al. [21] found that PLA significantly inactivated L. monocytogenes biofilm cells and that the bactericidal effect was enhanced with increasing PLA concentration.

The combination of ultrasound and PLA to inactivate foodborne pathogens in biofilms has not been reported. The aim of this study was to evaluate the combined effect of ultrasound and PLA on inactivating the biofilm cells of S. aureus and S. enteritidis and to explore the possible antibiofilm mechanism. Results provide a new method to control S. aureus and S. enteritidis biofilms in the food industry and other fields.

\section{Materials and Methods}

\subsection{Bacterial Cultivation}

S. aureus and S. enteritidis strains were stored at $-80^{\circ} \mathrm{C}$ and cultured in Brain Heart Infusion broth (BHI, Qingdao Rishui Bio-Technologies Co., Ltd., Qingdao, China) at $37^{\circ} \mathrm{C}$ for $24 \mathrm{~h}$. The strains were streaked on BHI agar and cultivated at $37^{\circ} \mathrm{C}$ for $24 \mathrm{~h}$. Individual colonies were inoculated in tubes containing $5 \mathrm{~mL}$ of $\mathrm{BHI}$ broth and transferred to fresh $\mathrm{BHI}$ broth every $24 \mathrm{~h}$, replicated three times. At the final culture stage, the bacterial count was confirmed by plating on BHI agar with a 1:10 series dilution.

\subsection{Treatment Parameters}

The concentrations of PLA used in the experiment were $0.5 \%$ and $1 \%(w / v)$. For the PLA treatments, mature S. aureus and S. enteritidis biofilms were treated with $0.5 \%$ and $1 \%$ PLA for different times. For the ultrasound (US) treatment, the mature biofilms were placed in an ultrasonic cleaning machine with $270 \mathrm{~W}$ and $50 \mathrm{kHz}$ (Kunshan Ultrasonic, Inc., Suzhou, China). For the combined treatments (US + 0.5\% PLA and US + 1\% PLA), the mature biofilm cells were immersed in $0.5 \%$ and $1 \%$ PLA and treated with US for different times.

\subsection{Biofilm Cultivation and Treatment}

Approximately $10^{7} \mathrm{CFU}(1 \mathrm{~mL})$ of $S$. aureus and S. enteritidis cells were added into each well of Nunc ${ }^{\mathrm{TM}}$ 24-Well Flat-Bottom Plates (ThermoFisher Scientific, Kamstrupvej, Denmark). The plates were cultured statically at $37^{\circ} \mathrm{C}$ for 3 days. BHI broth was changed every $24 \mathrm{~h}$ by removing the old medium along the walls of each well, and fresh medium was then added to maintain bacterial activity. After 3 days of cultivation, the supernatant was removed, and the biofilms were rinsed with $1 \mathrm{~mL}$ of $0.01 \mathrm{M}$ phosphate buffer (PBS) three times. The biofilms were subjected to different antibacterial treatments, including US $(270 \mathrm{~W}), 0.5 \%$ PLA, $1 \%$ PLA, and the combination of ultrasound and PLA (US + 0.5\% PLA, US $+1 \%$ PLA) for $5,10,20,30$, and 60 min, respectively. 


\subsection{Enumeration of Biofilm Cells}

A reduction in biofilm cells can directly reflect the antibacterial effect of different treatments on S. aureus and S. enteritidis biofilms. After different treatments, the water or chemicals in each well were replaced with $0.1 \mathrm{M}$ PBS and kept for $10 \mathrm{~min}$ before aspiration. A total of $1 \mathrm{~mL}$ of $0.01 \mathrm{M}$ PBS was then added to each well. The bacterial cells in each well were collected with a sterile cotton swab, and then diluted tenfold. The bacterial cells in the tube with an appropriate gradient were plated on BHI agar and cultured at $37^{\circ} \mathrm{C}$ for $24 \mathrm{~h}$ before counting.

\subsection{Polysaccharide Content in Biofilms}

After different treatments, the biofilm contents in each well were collected as above. The biofilm contents from the three wells corresponding to one sample were mixed and centrifuged at $6000 \times \mathrm{g}$ for $30 \mathrm{~min}$ at $4{ }^{\circ} \mathrm{C}$. The soluble polysaccharide content was determined using the supernatant. The concentrated precipitate was added to a solution $(0.85 \% \mathrm{NaCl}$, $0.22 \%$ formaldehyde) and heated for $30 \mathrm{~min}$ at $80{ }^{\circ} \mathrm{C}$. The solution was further centrifuged at $12,000 \times g\left(4{ }^{\circ} \mathrm{C}, 30 \mathrm{~min}\right)$, and the supernatant was used to determine the contents of insoluble polysaccharides in the biofilms. The polysaccharide contents were quantitatively determined by the phenol-sulfuric acid method [22].

\subsection{Confocal Laser Scanning Microscopy (CLSM) Analysis}

In brief, $400 \mu \mathrm{L}$ of approximately $10^{7} \mathrm{CFU} / \mathrm{mL}$ S. aureus or S. enteritidis was added to each well of the Nunc ${ }^{\mathrm{TM}}$ Lab-Tek ${ }^{\mathrm{TM}}$ chamber slides (ThermoFisher Scientific, Kamstrupvej, Denmark). The broth was changed every $24 \mathrm{~h}$ to keep the bacteria active. The biofilms in the chambers were treated according to the method in Section 2.3. The biofilms were dyed and observed according to previous reports [20,21].

\subsection{Scanning Electron Microscopy (SEM)}

Microstructural changes in the bacterial cells were further observed by SEM [19,20,23]. The cultivation and antibacterial treatment of S. aureus or S. enteritidis biofilms were conducted in accordance with the method in Section 2.3. After treatment, the slides were cut according to the sample grid by using a glass knife and completely immersed in $2.5 \%(v / v)$ glutaraldehyde solution. The samples were placed at $4{ }^{\circ} \mathrm{C}$ for $12 \mathrm{~h}$, dried, and placed again with $1 \%(v / v)$ osmic acid again for $90 \mathrm{~min}$. After gradient dehydration, the treated slides were sprayed with gold and observed using SEM (EVO-LS10, Zeiss, Jena, Germany). The magnification was selected as $\times 5000$ when taking pictures.

\subsection{Release of Intracellular ATP}

The mature biofilm cells of $S$. aureus and S. enteritidis cultured in a 24-well plate for 3 days were processed with different antibacterial treatments for $30 \mathrm{~min}$ according to the methodology in Section 2.3. After treatment, the supernatant was obtained by centrifugation at $10,000 \times g$ for $5 \mathrm{~min}$. The ATP content in the supernatant was detected using the ATP detection kit (Beyotime, Shanghai, China).

\subsection{Respiratory Chain Dehydrogenase (RCD) Determination}

The activity of RCD was determined by the triphenyltetrazole chloride (TTC) method according to a previous study [24]. The mature biofilm cells of S. aureus and S. enteritidis cultured in a 24-well plate for 3 days were subjected to different antibacterial treatments for $30 \mathrm{~min}$ according to the methodology in Section 2.3. After treatment, the bacterial suspension of $1.0 \mathrm{~mL}$ was mixed with $2 \mathrm{~mL}$ of $0.1 \mathrm{~mol} / \mathrm{L}$ glucose solution, $2 \mathrm{~mL}$ of $0.05 \mathrm{~mol} / \mathrm{L}$ Tris- $\mathrm{HCl}$ buffer $(\mathrm{pH}=8.6)$, and $2 \mathrm{~mL}$ of $1 \mathrm{mg} / \mathrm{mL}$ TTC solution. The mixture was kept in an incubator at $37^{\circ} \mathrm{C}$ for $5 \mathrm{~h}$ and $5 \mathrm{~mL}$ of chloroform was added. The lower organic phase was collected into a $10 \mathrm{~mL}$ centrifuge tube and centrifuged at $5000 \times g$ $\left(10 \mathrm{~min}, 4^{\circ} \mathrm{C}\right)$. The absorbance at $490 \mathrm{~nm}$ was measured. 


\subsection{Statistical Analysis}

All experiments were conducted in triplicate, of which the data were expressed as the mean \pm standard deviation (SD). Statistical analysis was done through ANOVA by using SPSS software version 26.0. The significance level between groups was set at $p<0.05$.

\section{Results}

\subsection{Inactivation of S. aureus and S. enteritidis Biofilm Cells}

Table 1 shows the effects of different treatments (ultrasound, PLA, and ultrasound combined with PLA) on inactivating the $S$. aureus bacterial cells in biofilms. The number of S. aureus cells in the control biofilm was approximately $9.4 \log \mathrm{CFU} / \mathrm{mL}$. The biofilm cells were not significantly reduced after treatment with single US for $30 \mathrm{~min}(p>0.05)$ and were only reduced by $0.3 \log \mathrm{CFU} / \mathrm{mL}$ when the treatment time was extended to $60 \mathrm{~min}$. Hence, single US treatment was not effective to inactivate $S$. aureus biofilm cells. The treatment of $1 \%$ PLA was more effective in significantly inactivating $S$. aureus biofilm cells than the treatment of $0.5 \%$ PLA $(p<0.05)$. S. aureus biofilm cells were inactivated by 0.4 and $0.9 \log$ $\mathrm{CFU} / \mathrm{mL}$ after treatments with $0.5 \%$ PLA for 5 and $30 \mathrm{~min}$ and by 1.7 and $3.6 \log \mathrm{CFU} / \mathrm{mL}$ after treatments with $1 \%$ PLA for 5 and $30 \mathrm{~min}$. The combined treatment of US + 0.5\% PLA for 5 and $30 \mathrm{~min}$ inactivated S. aureus biofilm cells by 1.7 and $3.4 \log \mathrm{CFU} / \mathrm{mL}$, respectively, similar to the $1 \%$ PLA treatment. These results showed that the combined treatment of ultrasound and PLA was significantly more effective than the single treatment $(p<0.05)$.

Table 1. Residual bacterial counts in S. aureus biofilms cells after the different treatments.

\begin{tabular}{|c|c|c|c|c|c|}
\hline \multirow{2}{*}{$\begin{array}{l}\text { Different } \\
\text { Treatments }\end{array}$} & \multicolumn{5}{|c|}{ S. aureus $\left(\log _{10} \mathrm{CFU} / \mathrm{mL}\right)$} \\
\hline & $5 \mathrm{~min}$ & $10 \mathrm{~min}$ & $20 \mathrm{~min}$ & $30 \mathrm{~min}$ & $60 \mathrm{~min}$ \\
\hline Control & $9.4 \pm 0.52 \mathrm{Aa}$ & $9.5 \pm 0.09 \mathrm{Aa}$ & $9.5 \pm 0.03 \mathrm{Aa}$ & $9.5 \pm 0.03 \mathrm{Aa}$ & $9.6 \pm 0.02 \mathrm{Ba}$ \\
\hline US & $9.3 \pm 0.49 \mathrm{Aa}$ & $9.3 \pm 0.18 \mathrm{Aa}$ & $9.1 \pm 0.10 \mathrm{Bb}$ & $9.1 \pm 0.24 \mathrm{Bab}$ & $9.3 \pm 0.13 \mathrm{Ab}$ \\
\hline $0.5 \%$ PLA & $9.0 \pm 0.02 \mathrm{Aa}$ & $8.9 \pm 0.01 \mathrm{Ab}$ & $8.9 \pm 0.09 \mathrm{Ac}$ & $8.6 \pm 0.07 \mathrm{Bb}$ & $7.9 \pm 0.37 \mathrm{Cb}$ \\
\hline $1 \%$ PLA & $7.7 \pm 0.04 \mathrm{Ab}$ & $7.6 \pm 0.24 \mathrm{Ac}$ & $6.9 \pm 0.08 \mathrm{Bd}$ & $5.9 \pm 0.55 \mathrm{Cc}$ & $5.8 \pm 0.27 \mathrm{Cc}$ \\
\hline US $+0.5 \%$ PLA & $7.7 \pm 0.33 \mathrm{Ab}$ & $7.6 \pm 0.37 \mathrm{Ac}$ & $6.8 \pm 0.08 \mathrm{Bd}$ & $6.1 \pm 0.36 \mathrm{Cc}$ & $5.7 \pm 0.31 \mathrm{Dc}$ \\
\hline US + 1\% PLA & $6.1 \pm 0.08 \mathrm{Bc}$ & $6.3 \pm 0.05 \mathrm{Ad}$ & $6.2 \pm 0.03 \mathrm{ABe}$ & $5.3 \pm 0.36 \mathrm{Cd}$ & $5.3 \pm 0.44 \mathrm{Cd}$ \\
\hline
\end{tabular}

Note: US, ultrasound; PLA, phenyllactic acid. Different upper cases (A-D) indicate significant differences of the data in the same row $(p<0.05)$. Different lower cases (a-e) indicate significant differences of the data in the same column $(p<0.05)$.

Table 2 presents the effects of different treatments on inactivating S. enteritidis bacterial cells in biofilms. The number of $S$. enteritidis cells in the control biofilm was approximately $8.5 \log \mathrm{CFU} / \mathrm{mL}$. S. enteritidis biofilm cells were inactivated by $0,0.2$, and $1.0 \log \mathrm{CFU} / \mathrm{mL}$ after a single treatment of US, $0.5 \%$ PLA, and 1\% PLA for $5 \mathrm{~min}$ and by $0.4,2.0$, and $3.1 \log \mathrm{CFU} / \mathrm{mL}$ when the treatment time reached $30 \mathrm{~min}$, respectively. S. enteritidis biofilm cells were inactivated by 4.8 and $5.0 \log \mathrm{CFU} / \mathrm{mL}$ after the combined treatments of US $+0.5 \%$ PLA and US + $1 \%$ PLA for $5 \mathrm{~min}$, respectively, which were significantly more effective than the single treatment $(p<0.05)$. Hence, ultrasound combined with PLA was more effective in inactivating $S$. enteritidis biofilm cells than the single treatment. The combined treatment of ultrasound and PLA significantly improved the efficiency of inactivating $S$. aureus and S. enteritidis biofilm cells $(p<0.05)$.

Table 2. Residual bacterial counts in S. enteritidis biofilms cells after the different treatments.

\begin{tabular}{|c|c|c|c|c|c|}
\hline \multirow{2}{*}{$\begin{array}{l}\text { Different } \\
\text { Treatments }\end{array}$} & \multicolumn{5}{|c|}{ S. enteritidis $\left(\log _{10} \mathrm{CFU} / \mathrm{mL}\right)$} \\
\hline & $5 \mathrm{~min}$ & $10 \mathrm{~min}$ & $20 \mathrm{~min}$ & $30 \mathrm{~min}$ & $60 \mathrm{~min}$ \\
\hline Control & $8.5 \pm 0.06 \mathrm{Aa}$ & $8.6 \pm 0.11 \mathrm{Aa}$ & $8.5 \pm 0.10 \mathrm{Aa}$ & $8.5 \pm 0.05 \mathrm{Aa}$ & $8.5 \pm 0.01 \mathrm{Aa}$ \\
\hline US & $8.5 \pm 0.04 \mathrm{Aab}$ & $8.5 \pm 0.21 \mathrm{Aa}$ & $8.4 \pm 0.09 \mathrm{Ab}$ & $7.6 \pm 0.24 \mathrm{Bb}$ & $7.5 \pm 0.13 \mathrm{Bb}$ \\
\hline $0.5 \%$ PLA & $8.3 \pm 0.04 \mathrm{Ab}$ & $7.7 \pm 0.24 \mathrm{Bb}$ & $7.6 \pm 0.06 \mathrm{Bc}$ & $6.5 \pm 0.19 \mathrm{Cc}$ & $5.7 \pm 0.08 \mathrm{Dc}$ \\
\hline $1 \%$ PLA & $7.5 \pm 0.07 \mathrm{Ac}$ & $7.4 \pm 0.03 \mathrm{ABc}$ & $7.3 \pm 0.06 \mathrm{Bd}$ & $5.4 \pm 0.42 \mathrm{Cd}$ & $5.3 \pm 0.15 \mathrm{Cd}$ \\
\hline
\end{tabular}


Table 2. Cont.

\begin{tabular}{|c|c|c|c|c|c|}
\hline \multirow{2}{*}{$\begin{array}{l}\text { Different } \\
\text { Treatments }\end{array}$} & \multicolumn{5}{|c|}{ S. enteritidis $\left(\log _{10} \mathrm{CFU} / \mathrm{mL}\right)$} \\
\hline & $5 \mathrm{~min}$ & $10 \mathrm{~min}$ & $20 \mathrm{~min}$ & $30 \mathrm{~min}$ & $60 \mathrm{~min}$ \\
\hline US $+0.5 \%$ PLA & $3.7 \pm 0.03 \mathrm{Ad}$ & $3.5 \pm 0.10 \mathrm{Bd}$ & $3.4 \pm 0.07 \mathrm{Be}$ & $3.2 \pm 0.15 \mathrm{Ce}$ & $3.1 \pm 0.09 \mathrm{Ce}$ \\
\hline US + 1\% PLA & $3.5 \pm 0.28 \mathrm{Ad}$ & $3.3 \pm 0.23 \mathrm{Bd}$ & $3.2 \pm 0.04 \mathrm{Bf}$ & $2.9 \pm 0.05 \mathrm{Ce}$ & $2.4 \pm 0.11 \mathrm{Df}$ \\
\hline
\end{tabular}

Note: US, ultrasound; PLA, phenyllactic acid. Different upper cases (A-D) indicate significant differences of the data in the same row $(p<0.05)$. Different lower cases $(\mathrm{a}-\mathrm{f})$ indicate significant differences of the data in the same column $(p<0.05)$.

\subsection{EPS Contents in Biofilms}

During the formation of bacterial biofilms, planktonic bacteria first adhere to the solid surface and then form a polymer matrix that is rich in proteins, nucleic acids, and extracellular polysaccharides (EPS); this matrix exhibits a protective effect against adverse environmental factors. EPS is the main component of the polymer matrix. Figure 1 shows the changes in the EPS contents in S. aureus and S. enteritidis biofilms after different treatments (US, $0.5 \%$ PLA, $1 \%$ PLA, US + 0.5\% PLA, and US + $1 \%$ PLA) for 30 min. As shown in Figure 1A, the soluble EPS content in the control S. aureus biofilm was $31.4 \mu \mathrm{g} / \mathrm{mL}$. After treatment with US, 0.5\% PLA, and 1\% PLA, the soluble EPS content in the biofilms decreased to $23.9,23.2$, and $16.1 \mu \mathrm{g} / \mathrm{mL}$, respectively. Treatments with US, $0.5 \%$ PLA, and $1 \%$ PLA reduced the soluble EPS content by $26.8 \%, 26.9 \%$, and $48.7 \%$, respectively. The combined treatment of US and PLA disrupted the EPS structure in the biofilm matrix, thereby destroying the integrity of the biofilms. Moreover, the combined treatment of US and 1\% PLA decreased the soluble EPS content in the biofilms to $5.9 \mu \mathrm{g} / \mathrm{mL}$. This finding indicates that the combination of ultrasound and PLA significantly reduced the insoluble EPS compared to ultrasound or PLA alone $(p<0.05)$. As shown in Figure $1 \mathrm{~B}$, the insoluble EPS content in the control S. aureus biofilm was $128.4 \mu \mathrm{g} / \mathrm{mL}$. After treatment with US, $0.5 \%$ PLA, $1 \%$ PLA, US + 0.5\% PLA, and US + $1 \%$ PLA, the insoluble EPS contents decreased to $108.6,103.7,95.5,87.8$, and $85.3 \mu \mathrm{g} / \mathrm{mL}$, respectively. Treatment with $1 \%$ PLA reduced the insoluble EPS content by $25.6 \%$, while the co-treatment of US + $0.5 \%$ PLA reduced the content by $31.6 \%$, indicating the synergistic effect of US and PLA on removing the biofilm matrix.

Based on Figure 1C,D, the changes in the soluble and insoluble EPS contents in S. enteritidis biofilms after different antibacterial treatment were similar to those of the S. aureus biofilms. The combined treatment of US and PLA significantly decreased the soluble and insoluble EPS contents than single US or PLA treatment $(p<0.05)$. Therefore, US and PLA had synergistic effects on destroying the biofilm matrix. When US and PLA was used together, US allowed the easy entry of PLA into the biofilm cells by increasing the permeability of the cell membrane, so PLA had a better antibacterial effect.

\subsection{CLSM Analysis}

The CLSM images of S. aureus and S. enteritidis biofilms after different treatments for $30 \mathrm{~min}$ are shown Figure 2. The control S. aureus and S. enteritidis biofilms were green (Figure 2(A1,B1)). The S. aureus and S. enteritidis biofilms treated with US for $30 \mathrm{~min}$ were yellowish-green (Figure 2(A4,B4)), indicating that most bacterial cells in the biofilms remained intact. The S. aureus and S. enteritidis biofilms treated with $0.5 \%$ PLA and $1 \%$ PLA for $30 \mathrm{~min}$ were green, yellow, and red (Figure 2(A2,A3,B2,B3)). With increasing PLA concentrations, the number of red cells increased. The S. aureus and S. enteritidis biofilms treated with US $+0.5 \%$ PLA and US $+1 \%$ PLA were almost completely red, indicating extremely serious damage to the biofilm cells. The CLSM images indicated that the combination of ultrasound and PLA was more effective to destroy cell membranes in foodborne pathogen biofilms than the single treatments. 

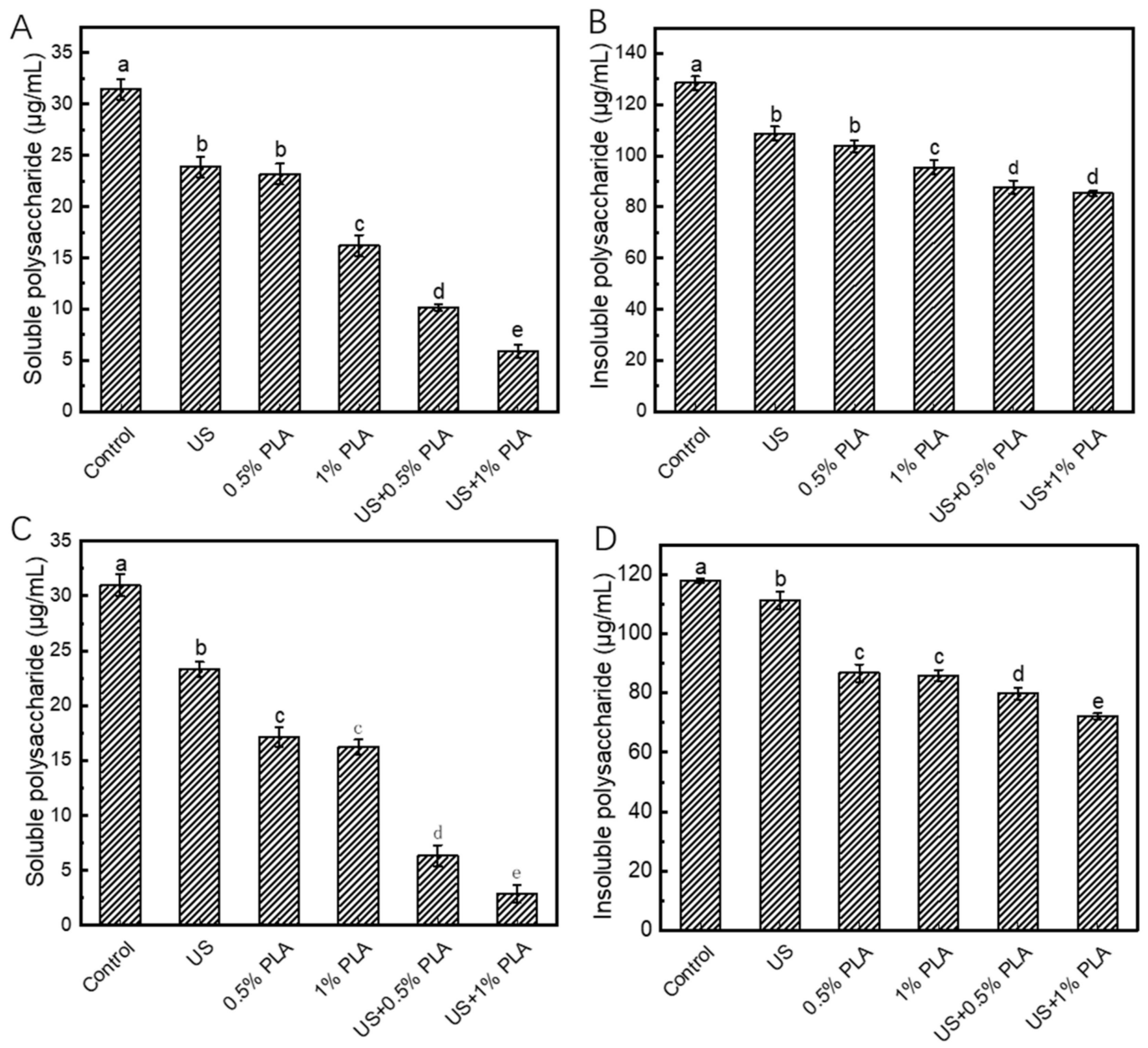

Figure 1. Changes in the contents of extracellular polysaccharides in S. aureus (A,B) and S. enteritidis (C,D) biofilms after different treatments. Different lower cases indicate significant difference $(p<0.05)$. US, ultrasound; PLA, phenyllactic acid.

\section{A Staphylococcus aureus}
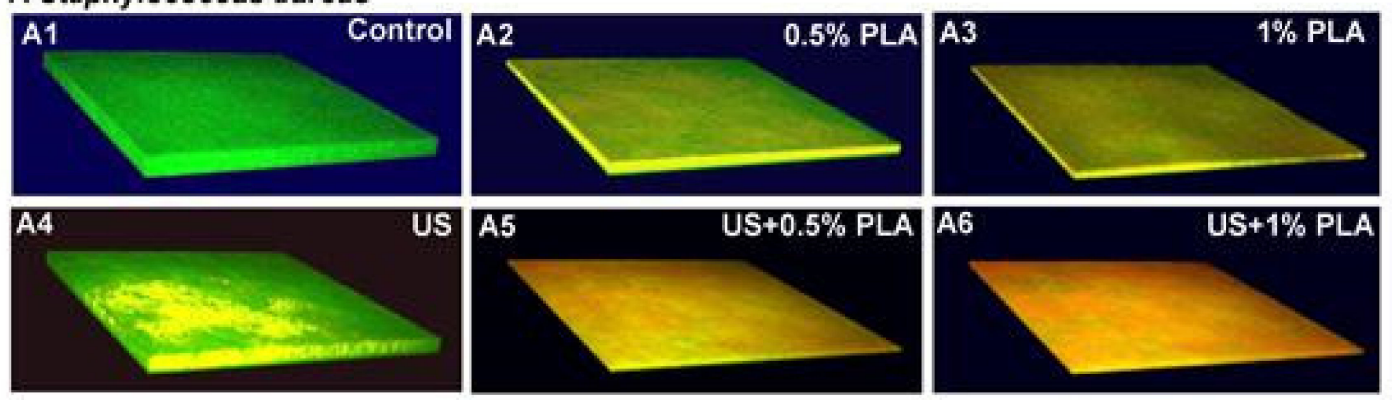

\section{B Salmonella enteritidis}
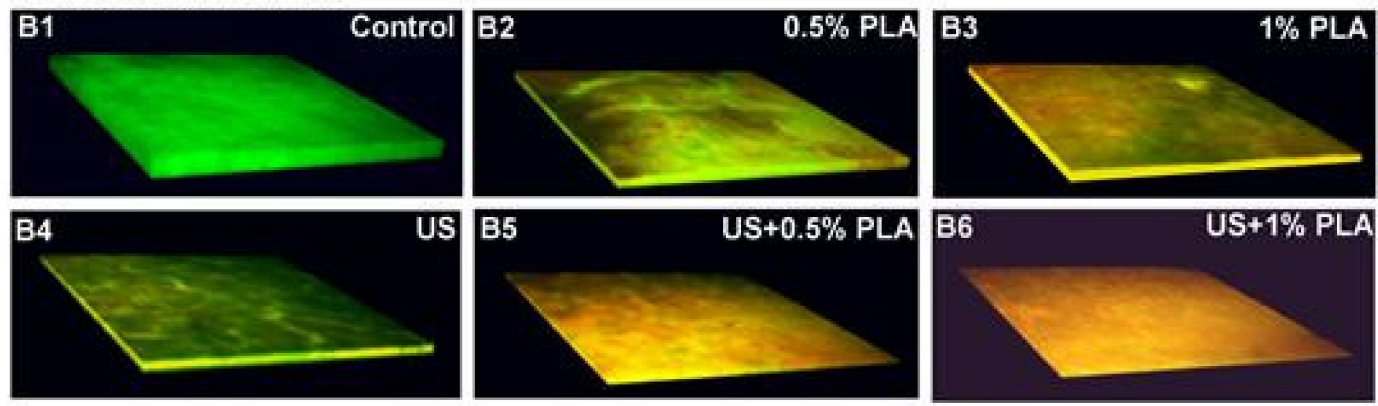

Figure 2. Confocal laser scanning images of S. aureus (A) and S. enteritidis (B) after the single and combined treatment of US and PLA for $30 \mathrm{~min}$. US: Ultrasound; PLA: Phenyllactic acid; US + PLA: Ultrasound combined with PLA. 


\subsection{SEM Analysis}

SEM was used to further analyze the effect of the combined treatment of US and PLA on the cell membrane damages of the S. aureus and S. enteritidis biofilm cells. The control bacterial cells of the $S$. aureus and S. enteritidis biofilms were surrounded by a large amount of EPS (Figure 3(A1,B1)). After treatment with ultrasound, 0.5\% PLA, and $1 \%$ PLA for $30 \mathrm{~min}$, the pathogen cells began to be exposed without the surrounding EPS (Figure 3(A2-A4,B2-B4)). Most of the S. aureus biofilm cells after single treatments still had cell structures (Figure 3(A4,B4)), while the $S$. enteritidis biofilm cells were seriously wrinkled (Figure 3(A2,A3,B2,B3)). The combination of ultrasound and PLA induced more obvious morphological damage to the bacterial cells (Figure 3(A5,A6,B5,B6)). The S. aureus biofilm cells began to shrivel (Figure 3(A5,A6)), and the S. enteritidis biofilm cells were thoroughly damaged and did not have intact cell structures (Figure 3(B5,B6)). Hence, ultrasound combined with PLA treatment caused more serious damage to the bacterial cells and biofilm matrix, consistent with the above results of bacterial inactivation and EPS content.
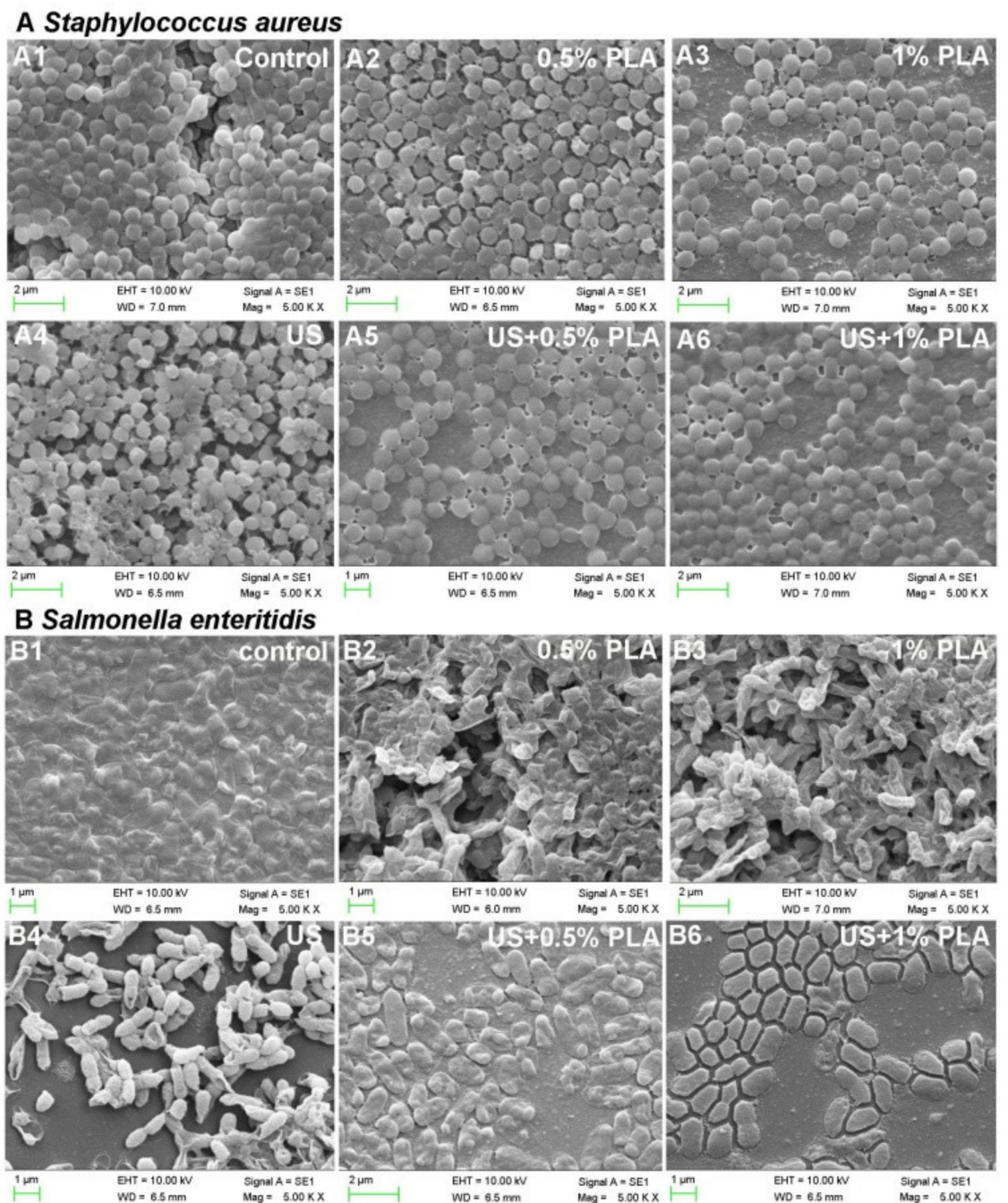

Figure 3. Scanning electron microscopy of S. aureus (A) and S. enteritidis (B) after the single and combined treatment of US and PLA for $30 \mathrm{~min}$. US, ultrasound; PLA, phenyllactic acid.

\subsection{Release of Intracellular ATP}

Extracellular ATP level is another indicator of cell damage. When the biofilm cells are damaged, ATP will be released from the cells. Figure 4 shows the changes in the extracellular ATP contents of the S. aureus and S. enteritidis biofilms after different antibacterial 
treatments. The contents of extracellular ATP of the control S. aureus and S. enteritidis biofilms were approximately 250 and $100 \mathrm{nmol} / \mathrm{OD}$, respectively. After treatments with US, $0.5 \%$ PLA, 1\% PLA, US + 0.5\% PLA, and US + 1\% PLA for $30 \mathrm{~min}$, the contents of extracellular ATP in the S. aureus biofilm increased to approximately 500, 1250, 1600, 1750, and $2750 \mathrm{nmol} / \mathrm{OD}$, respectively. As shown in Figure 4B, the extracellular ATP contents in the $S$. enteritidis biofilms increased to $227,446,689,925$, and $1480 \mathrm{nmol} / \mathrm{OD}$ after treatments with US, $0.5 \%$ PLA, $1 \%$ PLA, US + 0.5\% PLA, and US + 1\% PLA for $30 \mathrm{~min}$, respectively. The extracellular ATP level of the biofilm treated with US + 1\% PLA was significantly higher than that of the samples treated with the single US or PLA $(p<0.05)$. The combination of US and PLA was significantly more effective in causing damages to the cell structures and leakage of intracellular substances.

A

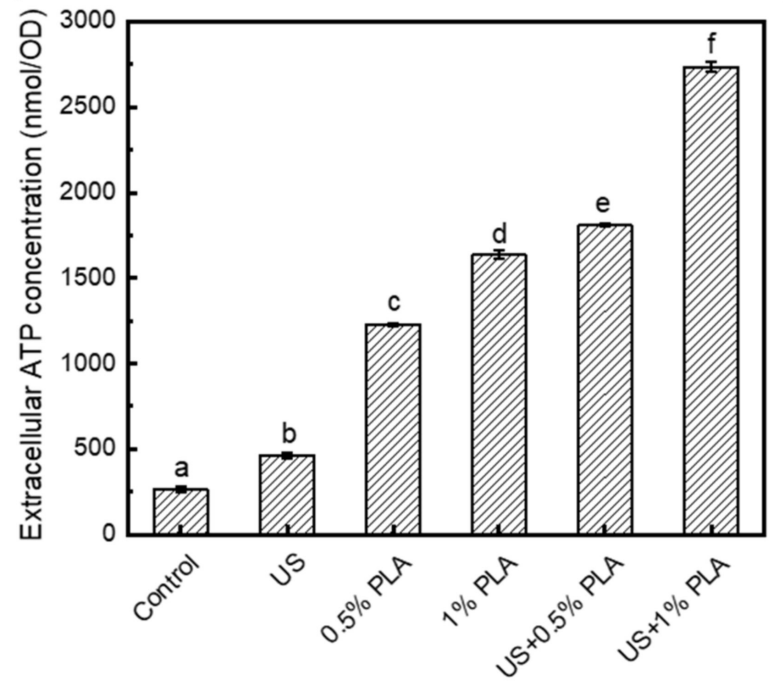

B

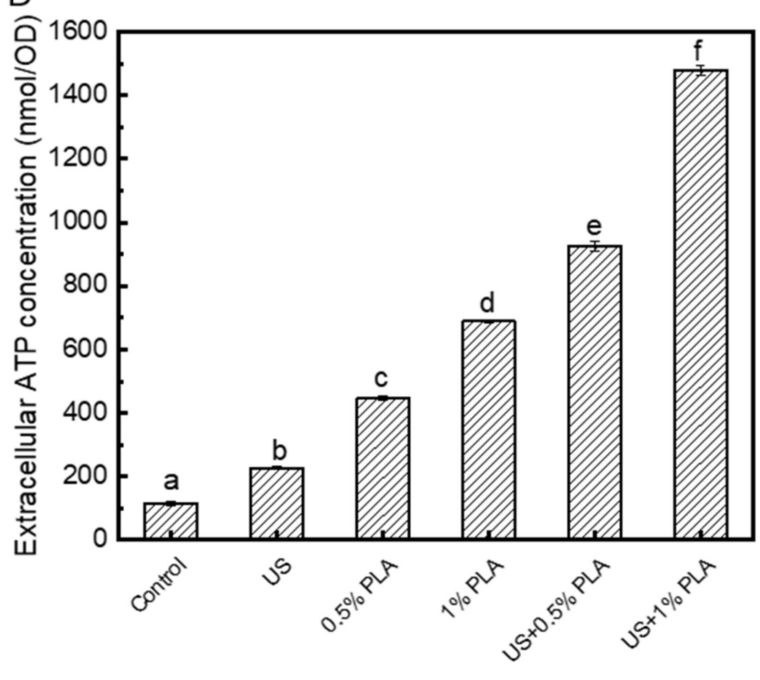

Figure 4. Changes in the contents of the extracellular ATP levels of S. aureus (A) and S. enteritidis (B) biofilm cells after different treatments. Different lower cases indicate significant difference $(p<0.05)$. US, ultrasound; PLA, phenyllactic acid.

\subsection{Activity of Respiratory Chain Dehydrogenase (RCD)}

The inactivation of bacterial RCD activity indicates that the bacterial mechanism pathway is interrupted, which results in bacterial death [25]. As shown in Figure 5A, the OD490 value of the control $S$. aureus biofilm cells representing the activity of RCD was about 0.47 . After treatment with US, the OD490 value decreased to 0.41 , indicating that the activity of RCA in the US-treated biofilm decreased by $14.9 \%$ compared to the control. After treatment with $0.5 \%$ and $1 \%$ PLA, the OD490 values decreased to 0.15 and 0.11 , indicating that the RCA activity in the two treated biofilm cells was decreased by $68.1 \%$ and $76.6 \%$, respectively. The activity of RCD was more easily inactivated by the PLA than US treatment. When the combined treatment of PLA and US was used, the reduction in RCD activity was significantly greater $(p<0.05)$ than that of the single $1 \%$ PLA treatment. As shown in Figure 5B, the single US and PLA treatment also decreased the activity of RCD in the S. enteritidis biofilm cells to different levels. The combination of US and PLA significantly decreased the activity of RCD in the S. enteritidis biofilm cells compared to the single treatments $(p<0.05)$. Hence, US treatment can help PLA to enter the biofilm cells, resulting in the inactivation of RCD at high levels. 

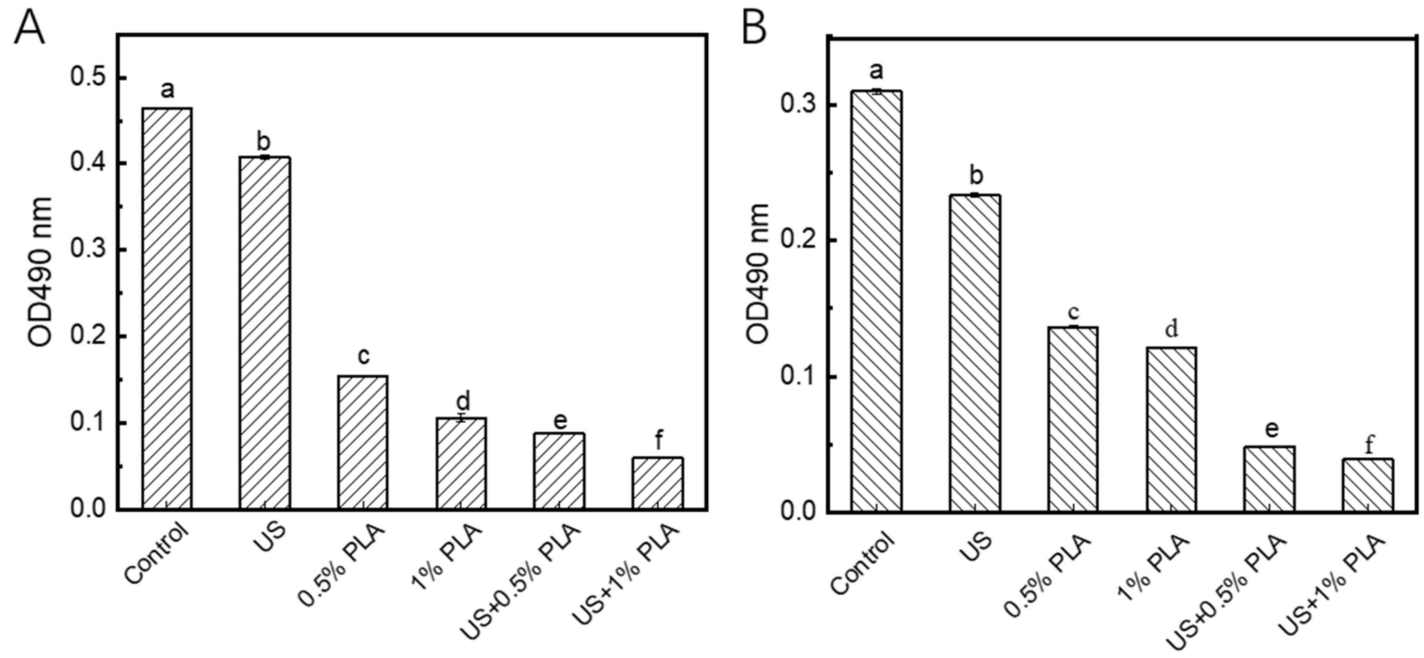

Figure 5. Changes in the activities of respiratory chain dehydrogenases in S. aureus (A) and S. enteritidis (B) biofilm cells. US, ultrasound; PLA, phenyllactic acid. Different letters indicate significant difference $(p<0.05)$.

\section{Discussion}

Food safety incidents caused by food-borne pathogen biofilms have attracted wide research attention. Many different antibacterial treatments have been used to eliminate or reduce the ability of food-borne pathogens to form biofilms [26-28]. Li et al. [29] found that ultrasonic treatment caused multi-target inactivation of S. aureus and E. coli due to different degrees of irreversible damages to the cell wall and plasma membrane. This finding is consistent with the report of Ashokkumar [30], who found that the mechanical force generated by ultrasound through cavitation damages microorganisms, leading to a bactericidal effect. Li et al. [29] also concluded that ultrasound sterilization can destroy the integrity of cell membranes, causing intracellular esterase inactivation and inhibiting cell metabolism. The sterilization mechanism of ultrasound has been explored. However, Gao et al. [31] found that although ultrasound treatment can damage bacterial cells through physical action, the probability of inactivating the bacteria is not high, similar to our research results. In the present study, differences between the US and control groups of S. aureus and S. enteritidis were almost insignificant, and the total number of colonies was not considerably different. The comparison of SEM and CLSM images showed limited difference between the US and control groups. Compared with the PLA treatment, the US treatment only changed the distance without causing too much cell breakage. This finding verifies that the role of ultrasound in the antibacterial process is through physical action to increase the cell membrane permeability but has no significant effect on killing bacteria. Based on analysis of the bacterial counts, changes in the RCD and ATP values, and changes in the SEM and CLSM images, the changes in the combined treatment group were more significant than those in the PLA treatment alone, and PLA treatment was significantly stronger than US treatment.

PLA is often used in production as an organic acid with broad-spectrum antibacterial activity. Mu et al. [32] found that PLA can simultaneously inhibit Gram-positive and Gram-negative bacteria, including common pathogenic bacteria, such as S. aureus and Salmonella. Lavermicocca et al. [33] and Schwenninger et al. [34] reported that PLA has a good inhibitory effect on yeasts and molds. Liu et al. [35] used PLA to treat Enterobacter cloacae and found that it had a significant antibacterial effect; that is, 1\% PLA treatment for $10 \mathrm{~min}$ can inactivate the biofilm by $2.8 \mathrm{log}$. In addition, Liu et al. [36] found that the combination of PLA and slightly acidic electrolyzed water was more effective to inactivate Klebsiella planktonic and biofilm cells than a single treatment. In the present study, for the first time, ultrasound and PLA were combined and their antibacterial effects against S. aureus and Salmonella biofilm cells were evaluated. The extracellular matrix in the biofilm contains a complex three-dimensional structure, and extracellular polysaccharides play 
a good protective role, leading to difficulty in removing the biofilm; as such, we innovatively adopted the combination of ultrasound and PLA to explore their joint bactericidal effect. Based on the changes in the various indicators tested, we can conclude the mechanism of ultrasound and PLA combined sterilization. Ultrasound increases the permeability of the cell membrane through cavitation and promotes the entry of PLA into bacterial cells to exert a bactericidal effect, thereby improving the sterilization ability.

Future studies should explore the combination of other sterilization methods to exert antibacterial effects. This work is the first to determine the antibacterial effect of ultrasound combined with PLA. The results provide a new and innovative antibacterial method for the food industry. PLA is often considered a green antibacterial agent owing to its natural origin; as such, the combination of US and PLA can be used to avoid the harmful effects of foodborne S. aureus and S. enteritidis in ready-to-eat meat and poultry products. At present, the cost of PLA usage is higher than the other typically used antibacterial agents due to the limitation of the large-scale industrial production of PLA. However, with the development of genetic engineering tools, PLA production will be enhanced by the fermentation of lactic acid bacteria strains. The application of PLA will be more popular due to the reduction in cost and because it satisfies the requirements for safe antibacterial agents.

\section{Conclusions}

US and PLA had a synergistic effect on inactivating the biofilm cells of S. aureus and S. enteritidis. The combined treatment significantly destroyed the cell membrane structures of the biofilm cells and led to the leakage of the internal components and inactivation of internal enzymes. In summary, US can further enhance the bactericidal effect of PLA by increasing the permeability of bacterial cells; as such, when the two methods were combined, they would have a stronger bactericidal effect than the single treatments.

Author Contributions: Conceptualization, F.L. and L.D.; investigation, J.Z. and F.L.; writing original draft preparation, J.Z. and D.W. (Debao Wang); formal analysis, J.S.; Z.S. and D.W. (Daoying Wang); writing-review and editing, F.L. and L.D. All authors have read and agreed to the published version of the manuscript.

Funding: The authors thank the funding from the National Natural Science Foundation of China (31871866), North Jiangsu Science and Technology Special Project of Jiangsu Province Policy Guidance Program (XZ-SZ202012), the Jiangsu postdoctoral research funding program (2021K349C), and the Postgraduate Research \& Practice Innovation Program of Jiangsu Province (SJCX20_1428).

Institutional Review Board Statement: Not applicable.

Informed Consent Statement: Not applicable.

Conflicts of Interest: The authors declare no conflict of interest or relationship.

\section{References}

1. Zhang, Y.; Liu, X.; Wang, Y.; Jiang, P.; Quek, S.Y. Antibacterial activity and mechanism of cinnamon essential oil against Escherichia coli and Staphylococcus aureus. Food Control 2016, 59, 282-289. [CrossRef]

2. Shao, T.; Dong, Y.; Chen, X.J.; Xu, X.L.; Wang, H.H. Modeling the elimination of mature biofilms formed by Staphylococcus aureus and Salmonella spp. using combined ultrasound and disinfectants. Ultrason. Sonochem. 2020, 69, 105269. [CrossRef]

3. Sharahi, J.Y.; Azimi, T.; Shariati, A.; Safari, H.; Tehrani, M.K.; Hashemi, A. Advanced strategies for combating bacterial biofilms. J. Cell. Physiol. 2019, 234, 14689-14708. [CrossRef]

4. Omwenga, I.; Aboge, G.O.; Mitema, E.S.; Obiero, G.; Ngaywa, C.; Ngwili, N.; Wamwere, G.; Wainaina, M.; Bett, B. Staphylococcus aureus enterotoxin genes detected in milk from various livestock species in northern pastoral region of Kenya. Food Control 2019, 103, 126-132. [CrossRef]

5. Sun, J.L.; Zhang, S.K.; Chen, J.Y.; Han, B.Z. Efficacy of acidic and basicelectrolyzed water in eradicating Staphylococcus aureus biofilm. Can. J. Microbiol. 2012, 58, 448-454. [CrossRef]

6. Jung, Y.G.; Matthews, K.R. Potential transfer of extended spectrum $\beta$-lactamase encoding gene, blashv18 gene, between Klebsiella pneumoniae in raw foods. Food Microbiol. 2020, 60, 39-48. [CrossRef] [PubMed] 
7. Pontin, K.P.; Borges, K.A.; Furian, T.Q.; Carvalho, D.; Wilsmann, D.E.; Cardoso, H.R.P.; Alves, A.K.; Chitolina, G.Z.; Salle, C.T.P.; Moraes, H.L.D.S.; et al. Antimicrobial activity of copper surfaces against biofilm formation by Salmonella enteritidis and its potential application in the poultry industry. Food Microbiol. 2020, 94, 103645. [CrossRef]

8. Wu, H.; Wang, M.; Liu, Y.; Wang, X.; Wang, Y.; Lu, J.; Xu, H. Characterization of antimicrobial resistance in Klebsiella species isolated from chicken broilers. Int. J. Food Microbiol. 2016, 232, 95-102. [CrossRef] [PubMed]

9. Yuan, L.; Hansen, M.F.; Roeder, H.L.; Wang, N.; Burmølle, M.; He, G. Mixed-species biofilms in the food industry: Current knowledge and novel control strategies. Crit. Rev. Food Sci. Nutr. 2019, 60, 2277-2293. [CrossRef]

10. Yu, H.; Seow, Y.X.; Ong, P.K.; Zhou, W. Effects of high-intensity ultrasound on Maillard reaction in a model system of d-xylose and 1-lysine. Ultrason. Sonochem. 2017, 34, 154-163. [CrossRef]

11. Techathuvanan, C.; D'Souza, D.H. High intensity ultrasound for Salmonella enteritidis Inactivation in culture and liquid whole eggs. J. Food Sci. 2018, 83, 1733-1739. [CrossRef] [PubMed]

12. Cameron, M.; McMaster, L.D.; Britz, T.J. Impact of ultrasound on dairy spoilage microbes and milk components. Dairy Sci. Technol. 2009, 89, 83-98. [CrossRef]

13. Chemat, F.; Huma, Z.E.; Khan, M.K. Applications of ultrasound in food technology: Processing, preservation and extraction. Ultrason. Sonochem. 2011, 18, 813-835. [CrossRef] [PubMed]

14. Bang, H.-J.; Park, S.Y.; Kim, S.E.; Rahaman, M.M.F.; Ha, S.-D. Synergistic effects of combined ultrasound and peroxyacetic acid treatments against Cronobacter sakazakii biofilms on fresh cucumber. LWT 2017, 84, 91-98. [CrossRef]

15. Selan, L.; Papa, R.; Barbato, G.; Scoarughi, G.L.; Vrenna, G.; Artini, M. Ultrasound affects minimal inhibitory concentration of ampicillin against methicillin resistant Staphylococcus aureus USA300. New Microbiol. 2019, 42, 52-54.

16. Alenyorege, E.A.; Ma, H.; Ayim, I.; Aheto, J.H.; Hong, C.; Zhou, C. Reduction of Listeria innocua in fresh-cut Chinese cabbage by a combined washing treatment of sweeping frequency ultrasound and sodium hypochlorite. LWT 2018, 101, 410-418. [CrossRef]

17. Duarte, A.L.A.; Rosario, D.K.A.D.; Oliveira, S.B.S.; de Souza, H.L.S.; de Carvalho, R.V.; Carneiro, J.C.S.; Silva, P.I.; Bernardes, P.C. Ultrasound improves antimicrobial effect of sodium dichloroisocyanurate to reduce Salmonella Typhimurium on purple cabbage. Int. J. Food Microbiol. 2018, 269, 12-18. [CrossRef]

18. Meireles, A.; Machado, I.; Fulgêncio, R.; Mergulhão, F.; Melo, L.; Simões, M. Efficacy of antimicrobial combinations to reduce the use of sodium hypochlorite in the control of planktonic and sessile Escherichia coli. Biochem. Eng. J. 2015, 104, 115-122. [CrossRef]

19. Sagong, H.G.; Lee, S.Y.; Chang, P.S.; Heu, S.; Ryu, S.; Choi, Y.J.; Kang, D.H. Combined effect of ultrasound and organic acids to reduce Escherichia coli 0157:H7, Salmonella Typhimurium, and Listeria monocytogenes on organic fresh lettuce. Int. J. Food Microbiol. 2011, 145, 287-292. [CrossRef]

20. Liu, F.; Sun, Z.; Wang, F.; Liu, Y.; Zhu, Y.; Du, L.; Wang, D.; Xu, W. Inhibition of biofilm formation and exopolysaccharide synthesis of Enterococcus faecalis by phenyllactic acid. Food Microbiol. 2019, 86, 103344. [CrossRef]

21. Liu, F.; Du, L.; Zhao, T.; Zhao, P.; Doyle, M.P. Effects of phenyllactic acid as sanitizing agent for inactivation of Listeria monocytogenes biofilms. Food Control 2017, 78, 72-78. [CrossRef]

22. Dubois, M.; Gilles, K.A.; Hamilton, J.K.; Rebers, P.A.; Smith, F. Colorimetric method for determination of sugars and related substances. Anal. Chem. 1956, 28, 350-356. [CrossRef]

23. Tang, H.; Chen, W.; Dou, Z.; Chen, R.; Hu, Y.; Chen, W.; Chen, H. Antimicrobial effect of black pepper petroleum ether extract for the morphology of Listeria monocytogenes and Salmonella typhimurium. J. Food Sci. Technol. 2017, 54, 2067-2076. [CrossRef]

24. Richter, A.K.; Frossard, E.; Brunner, I. Polyphenols in the woody roots of Norway spruce and European beech reduce TTC. Tree Physiol. 2007, 27, 155-160. [CrossRef]

25. Liu, X.; Cai, J.; Chen, H.; Zhong, Q.; Hou, Y.; Chen, W.; Chen, W. Antibacterial activity and mechanism of linalool against Pseudomonas aeruginosa. Microb. Pathog. 2020, 141, 103980. [CrossRef]

26. Bragason, E.; Berhe, T.; Dashe, D.; Sørensen, K.I.; Guya, M.E.; Hansen, E.B. Antimicrobial activity of novel Lactococcus lactis strains against Salmonella Typhimurium DT12, Escherichia coli O157:H7 VT - and Klebsiella pneumoniae in raw and pasteurised camel milk. Int. Dairy J. 2020, 111, 104832. [CrossRef]

27. Kang, J.-W.; Lee, H.-Y.; Kang, D.-H. Synergistic bactericidal effect of hot water with citric acid against Escherichia coli O157:H7 biofilm formed on stainless steel. Food Microbiol. 2020, 95, 103676. [CrossRef]

28. Zhang, Y.; Huang, H.H.; Duc, H.M.; Masuda, Y.; Honjoh, K.I.; Miyamoto, T. Endolysin LysSTG2: Characterization and application to control Salmonella Typhimurium biofilm alone and in combination with slightly acidic hypochlorous water. Food Microbiol. 2021, 98, 103791. [CrossRef]

29. Li, J.; Ahn, J.; Liu, D.; Chen, S.; Ye, X.Q.; Ding, T. Evaluation of ultrasound-induced damage to Escherichia coli and Staphylococcus aureus by Flow Cytometry and Transmission Electron Microscopy. Appl. Environ. Microbiol. 2016, 82, 1828-1837. [CrossRef]

30. Ashokkumar, M. The characterization of acoustic cavitation bubbles-An overview. Ultrason. Sonochem. 2011, 18, 864-872. [CrossRef]

31. Gao, S.; Hemar, Y.; Ashokkumar, M.; Paturel, S.; Lewis, G. Inactivation of bacteria and yeast using high-frequency ultrasound treatment. Water Res. 2014, 60, 93-104. [CrossRef] [PubMed]

32. $\mathrm{Mu}, \mathrm{W}$; Yu, S.; Zhu, L.; Zhang, T.; Jiang, B. Recent research on 3-phenyllactic acid, a broad-spectrum antimicrobial compound. Appl. Microbiol. Biotechnol. 2012, 95, 1155-1163. [CrossRef] [PubMed]

33. Lavermicocca, P.; Valerio, F.; Visconti, A. Antifungal activity of phenyl-lactic acid against molds isolated from bakery products. Appl. Environ. Microbiol. 2003, 69, 634-640. [CrossRef] 
34. Schwenninger, S.M.; Lacroix, C.; Truttmann, S.; Jans, C.; Spörndli, C.; Bigler, L.; Meile, L. Characterization of Low-MolecularWeight antiyeast metabolites produced by a food-protective Lactobacillus-Propionibacterium Coculture. J. Food Prot. 2008, 71, 2481-2487. [CrossRef] [PubMed]

35. Liu, F.; Wang, F.; Du, L.; Zhao, T.; Doyle, M.P.; Wang, D.; Zhang, X.; Sun, Z.; Xu, W. Antibacterial and antibiofilm activity of phenyllactic acid against Enterobacter cloacae. Food Control 2018, 84, 442-448. [CrossRef]

36. Liu, F.; Tang, C.; Wang, D.; Sun, Z.; Du, L.; Wang, D. The synergistic effects of phenyllactic acid and slightly acid electrolyzed water to effectively inactivate Klebsiella oxytoca planktonic and biofilm cells. Food Control 2020, 125, 107804. [CrossRef] 